\title{
STRATEGI GURU PAI DALAM MENGEMBANGKAN KECERDASAN EMOSIONAL SISWA KELAS VI SD
}

\section{Marisca Oktaria}

Universitas Islam Negeri Raden Fatah

Palembang

marisca.oktaria@gmail.com

\section{Karoma}

Universitas Islam Negeri Raden Fatah

Palembang

karoma_uin@radenfatah.ac.id

\begin{abstract}
Abstrak
Teacher strategies in the learning process that are less precise can cause students to be inactive and focused in learning, students are less enthusiastic and some students are noisy in the classroom. This is because teachers pay more attention to students 'intellectual intelligence and pay less attention to students' emotional intelligence in learning activities. The purpose of this study was to determine the emotional intelligence of Grade VI students in Palembang 214 Public Elementary School and to find out the PAI teacher's strategy in developing the emotional intelligence of Grade VI students in Palembang 214 Public Elementary School.

The research method used is descriptive qualitative analysis that discusses the PAI teacher's strategy in developing emotional intelligence of grade VI students in 214 Negeri SD Palembang. The type of approach used in this research is descriptive qualitative with data collection techniques through observation, interviews, documentation and triangulation. Analysis of data qualitatively through three stages, namely data reduction, data presentation and conclusion stages.
\end{abstract}

The results of this study that the PAI Teacher Strategy in Developing Emotional Intelligence of Class VI Students at 214 Public Elementary Schools in Palembang. First, learning includes interactive activities, namely the existence of good lead in learning. Inspirational, which is to let students act and think according to their inspiration. The fun that can be created from a neat and attractive room arrangement. Challenging, namely learning must develop students' curiosity. Motivation, which is to give appreciation and encourage students' interest in learning. Second, emotional intelligence possessed by students includes self-awareness, ie students can recognize their emotions. Self control, which is able to express feelings. Motivation, which has a desire to achieve goals. Empathy, namely students can understand the feelings of others. And social abilities, which are able to interact well.

Keyword: Strategy, Teacher and Emotional Intelligence 


\section{PENDAHULUAN}

Pendidikan disekolah berlangsung apabila ada guru dan siswa. Peran guru tersebut dapat diwujudkan melalui strategi pembelajaran. Salah satu peranan penting guru disekolah adalah mengembangkan kecerdasan emosional termasuk melalui pembelajaran Pendidikan Agama Islam. Kecerdasan manusia terbagi 3 yaitu kecerdasan intelektual (kognitif), kecerdasan emosional (sikap sosial), dan kecerdasan spiritual (sikap rohani). Tiga kecerdasan ini diharapkan bisa dimiliki anak sehingga mampu menjadi individu yang mandiri dan memiliki jiwa yang tangguh. ${ }^{1}$

Salah satu sarana yang dapat membantu mengembangkan ketiga hal tersebut adalah pendidikan disekolah. Untuk ini perlu strategi pembelajaran, yang relevan dengan materi dan kebutuhan belajar siswa. Strategi pembelajaran terkait dengan materi yang akan disampaikan, metode yang akan digunakan untuk penyampaian dalam proses pembelajaran dengan siswa termasuk umpan balik pembelajaran dan evaluasi yang digunakan. ${ }^{2}$

Keseimbangan IQ dan EQ sangat diperlukan agar peserta didik dapat berpartisipasi pada proses pembelajaran. Dua kecerdasan tersebut dapat didorong oleh guru dengan mengoptimalkan potensi peserta didik. Guru seyogyanya tidak hanya bisa mengarahkan perkembangan rational intelligence atau pemahaman logika peserta didik yang hanya mengacuh pada buku belajar, tetapi juga perlu mengembangkan kecerdasan emosional peserta didik. ${ }^{3}$ Setinggi-tingginya IQ memberikan pengaruh kurang lebih 20 persen bagi faktor-faktor yang menentukan kesuksesan dalam hidup, jadi 80 persen lainnya merupakan kekuatan-kekuatan lain, termasuk kecerdasan emosional. ${ }^{4}$

Hal ini menyatakan bahwa jika hanya kecerdasan IQ belum dapat menjamin seorang menjadi sukses dikemudian hari, karena kecerdasan IQ jika tidak diikuti dengan kecerdasan emosi yang baik sulit menghasilkan seseorang yang sukses. Dengan demikian pemahaman bahwa kecerdasan IQ bukanlah satu-

${ }^{1}$ Mahmud, Psikologi Pendidikan (Bandung: Pustaka Setia, 2012), hal. 15.

${ }^{2}$ Darmansyah, Strategi Pembelajaran Menyenangkan dengan Humor (Jakarta: Bumi Aksara, 2012), hal. 17.

${ }^{3}$ A Kang Mastur, Humor Guru Sufi (Banjarmasin: Diva Pres, 2016), hal. 59.

${ }^{4}$ Daniel Goleman, Emotional Intelligence: Kecerdasan Emosional (Jakarta: Gramedia Pustaka Utama, 2015), hal. 42. 
satunya aspek yang menentukan keberhasilan hidup seseorang, tampaknya sudah mahfum dikalangan masyarakat. ${ }^{5}$

Memperhatikan emosi siswa dapat membantu guru mempercepat pembelajaran siswa. Memahami emosi siswa dapat membuat pembelajaran lebih berarti dan permanen. Penelitian-penelitian tentang otak semakin menunjukan adanya hubungan antara keterlibatan emosi serta memori jangka panjang dengan belajar. Perlibatan emosi mempengaruhi kegiatan saraf otak, tanpa keterlibatan emosi saraf otak berkurang dari yang dibutuhkan untuk merekatkan pelajaran dalam ingatan. ${ }^{6}$

Ketika guru menerapkan strategi pembelajaran yang kurang tepat dalam proses pembelajaran biasanya situasi kondisi kelas tidak terkelola dengan baik akibatnya siswa bosan dan kurang menarik perhatian siswa sehingga membuat siswa kurang termotivasi dan kurang bersemangat dalam mengikuti proses belajar, hal ini menyebabkan siswa menjadi pasif dan tidak aktif dalam pembelajaran. Sebaliknya jika guru dapat menerapkan strategi yang tepat dalam kegiatan pembelajaran tentu akan menciptakan dampak yang baik bagi siswa, siswa akan bersemangat, aktif, tidak bosan, serta tujuan pembelajaran akan tercapai sesuai yang diharapkan. ${ }^{7}$

Sementara itu di SD Negeri 214 Palembang pada kelas VI terlihat bahwa guru PAI sudah menggunakan strategi pembelajaran yang dapat menarik minat siswa dalam belajar, guru menggunakan strategi pembelajaran yang dapat membuat siswa aktif dan antusias dalam belajar, siswa menjadi nyaman dalam mengikuti proses belajar mengajar yang berlangsung. Strategi pembelajaran yang dilakukan salah satunya seperti menggunakan metode pembelajaran yang bervariasi, memberikan apresiasi kepada siswa serta dalam proses pembelajaran guru juga berusaha menyelesaikan permasalahan yang dihadapi siswa dengan benar tanpa menyinggung atau membuat siswa takut, guru dapat menjalin

${ }^{5}$ Eli Manizar HM, "Mengelola Kecerdasan Emosi," Tadrib: Jurnal Pendiidkan Agama Islam 2, no. 2 (2017): hal. 198-213.

${ }^{6}$ Mahmud, op. cit., hal. 296.

${ }^{7}$ Observasi, di SD Negeri 218 Palembang, pada 13-15 Februari 2019. 
hubungan yang baik terhadap siswa. Dengan penerapan strategi pembelajaran yang baik kecerdasan emosional siswa dapat berkembang. ${ }^{8}$

\section{METODE PENELITIAN}

Penelitian ini menggunakan jenis penelitian kualitatif. Penggunaan penelitian ini disesuaikan dengan tujuan pokok penelitian, yaitu mendeskripsikan dan menganalisis mengenai strategi guru pai dalam mengembangkan kecerdasan emosional siswa kelas VI di SD Negeri 214 Palembang. Pendekatan penelitian yang digunakan adalah pendekatan kualitatif, pendekatan kualitatif adalah pendekatan penelitian yang datanya dinyatakan dalam bentuk verbal dan analisis tanpa menggunakan teknik statistik. Jenis data yang dihimpun dalam penelitian ini adalah data kualitatif, data kualitatif ialah data yang bersifat menguraikan, menggambarkan, membandingkan dan diklasifikasikan sesuai jenisnya kemudian ditarik suatu kesimpulan yaitu tentang strategi guru dalam mengembangkan kecerdasan emosional siswa. Jadi peneliti ini bersifat kualitatif yang dijabarkan dengan kata-kata dan kalimat.

Adapun sumber data yang diperlukan dalam penelitian ini adalah sumber data primer dan sumber data sekunder. Data primer adalah sumber data yang langsung memberikan data kepada pengumpul data. Sedangkan data sekunder adalah sumber data yang tidak langsung memberikan data kepada pengumpul data, misalnya lewat orang lain atau lewat dokumen. ${ }^{9}$

Selanjutnya teknik pengumpulan data yang digunakan dalam penelitian ini ada empat. Pertama observasi adalah pengamatan yang dilakukan secara langsung oleh peneliti dengan menggunakan penglihatan tanpa mengajukan pertanyaan terhadap objek pengamatan. Kedua wawancara adalah suatu kejadian atau suatu proses interaksi antara pewawancara dan sumber informasi atau orang yang diwawancarai melalui komunikasi langsung. Ketiga dokumen merupakan cacatan peristiwa yang sudah berlalu. Dokumen bisa berbentuk tulisan, gambar, atau karya-karya monumental dari seseorang. Keempat triangulasi diartikan sebagai teknik pengumpulan data yang bersifat menggabungkan dari berbagai teknik

${ }^{9}$ Sugiyono, Metode Penelitian Kualitatif (Bandung: Alfabeta, 2017), hal. 104. 
pengumpulan data yang sekaligus menguji kredibilitas data dan berbagai sumber data. $^{10}$

Adapun analisis data menggunakan empat data. Pertama pengumpulan data merupakan kegiatan utama pada setiap penelitian adalah mengumpulkan data. Dalam penelitian kualitatif pengumpulan data dengan observasi, wawancara, dan dokumentasi atau gabungan ketiganya (triangulasi) . Kedua reduksi data berarti merangkum, memilih hal-hal yang pokok, memfokuskan pada hal-hal yang penting, dicari tema dan polanya. Ketiga data display, penyajian data bisa dilakukan dalam bentuk uraian singkat, bagan, hubungan atar kategori dan sejenisnya. Yang paling sering digunakan untuk menyajikan data dalam penelitian kualitatif adalah dengan teks yang bersifat naratif. Keempat verification merupakan penarikan kesimpulan yakni makna-makna yang muncul dari data yang harus diuji kebenarannya dan kecocokannya yang berupa validitas. ${ }^{11}$

\section{HASIL DAN PEMBAHASAN}

A. Strategi Guru PAI dalam Mengembangkan Kecerdasan Emosional Siswa Kelas VI di SD Negeri 214 Palembang

1. Interaktif

Interaktif adalah suatu hal yang berkaitan dengan komunikasi dua arah, suatu hal yang bersifat saling melakukan tindakan, saling berperan dan saling berhubungan serta melakukan timbal balik antara yang satu dengan yang lainnya. Karena pada umumnya terjadinya interaksi belajar mengajar yakni, terjadinya antara tiga unsur yaitu guru, anak didik dan bahan. Bahan sebagai isi dari proses belajar mengajar yang disampaikan guru untuk diterima oleh siswa. Bahan disini sebagai perantara untuk terjadinya interaksi belajar mengajar antara guru dengan siswa dengan itu tanpa bahan tidak akan terjadi interaksi belajar mengajar. ${ }^{12}$

Interaksi antara guru dan siswa, dari hasil observasi yang dilakukan interaksi antara guru dan siswa ini terjalin dengan sangat

\footnotetext{
${ }^{10}$ Ibid., hal. 125.

${ }^{11}$ Ibid., hal. 142.

${ }^{12}$ Nurlaila, Pengelolaan Pengajaran (Palembang: Noer Fikri, 2015), hal. 143.
} 
baik, hal ini terlihat ketika guru menyampaikan materi dan siswa mendengarkan dengan baik serta jika ada yang kurang dimengerti siswa langsung menanyakannya kepada siswa. Begitupun guru ketika sudah menyejalaskan langsung bertanya kepada siswa apakah masih ada yang belum di mengerti atau menanyakan sesuatu kepada siswa, serta untuk menjawab pertanyaan siswa. ${ }^{13}$

Interaksi antara siswa dan siswa, interaksi yang lain adalah interaksi antara siswa dan siswa, interaksi ini merupakan interaksi yang penting juga selain antara guru dan siswa, siswa dan siswa pun perlu menjalin interaksi dengan baik. Dari observasi yang dilakukan interaksi antara siswa dan siswa terlihat jelas, seperti dalam proses pembelajaran guru biasanya menyuruh siswa untuk melakukan diskusi atau kerja kelompok dalam kegiatan itulah interaksi dan komunikasi siswa antara siswa yang lain berjalan dengan baik. ${ }^{14}$

Interaksi pengembangan mental, seperti yang dilihat dari hasil observasi interaksi pengembangan mental ini terlihat dari cara guru dalam melakukan pendekatan kepada siswa. Guru melakukan pendekatan dengan siswa yang cukup kurang dalam segi nilai serta lama dapat penyerapan materi yang diajarkan, guru memberikan motivasi yang lebih kepada siswa tersebut agar mereka bersemangat dalam belajar dan berusaha agar siswa tersebut berusaha untuk belajar dengan lebih giat. ${ }^{15}$

Interaksi pengembangan intelektual, dari hasil observasi yang saya lihat interaksi pengembangan intelektual ini terlihat pada saat guru memulai pembelajaran, materi yang disampaikan guru atau pun kegiatan bertanya jawab merupakan upaya guru dalam melakukan interaksi pengembangan intelektual untuk siswa. Dengan bahan ajar yang diberikan interaksi pengembangan intelektual ini berjalan dengan baik karena pada proses pembelajaran siswa sudah 
memperhatikan dan memahami apa yang disampaikan oleh guru tersebut. ${ }^{16}$

2. Inspiratif

Proses pembelajaran ialah sistem yang inspiratif, yang menciptakan perilaku siswa untuk mencoba melakukan susuatu, dengan membiarkan siswa berbuat dan berpikir sesuai dengan kreativitasnya sendiri, maka siswa akan memperoleh pengetahuan yang pada dasarnya bersifat subjektif dan bisa dimaknai oleh setiap siswa. ${ }^{17}$

Siswa berbuat dan berpikir sesuai dengan inspirasinya, seperti yang terlihat pada saat observasi, guru telah memberikan ruang kepada siswa untuk berbuat dan berpikir sesuai yang mereka inginkan, seperti pada proses pembelajaran guru membiarkan siswa untuk bertanya apapun baik yang berkaitan dengan materi yang disampikan ataupun di luar materi yang sedang disampikan guru. Serta dalam metode pelajaran yang dilakukan guru untuk menyuruh siswa memahami materi yang sedang dipelajari kemudian menugaskan siswa untuk menjelaskan kembali materi yang dipelajari tersebut dengan cara dan pengertian siswa itu sendiri. ${ }^{18}$

Proses belajar yang inspiratif, dalam kegiatan observasi proses belajar inspiratif ini terlihat dari guru yang sebisa mungkin untuk menunjukan sikap dan karakter yang baik dihadapan siswa, dengan menjaga penampilan, bersemangat dalam menyampaikan materi pelajaran, bersikap murah senyum tidak selalu marah-marah kepada siswa, serta guru dapat menanamkan contoh dari sebuah kisah yang inspiratif yang dapat menjadi panutan bagi siswa, seperti kisah-kisah Nabi diselah-selah penjelasan materi yang sedang disampaikan. ${ }^{19}$

\footnotetext{
${ }^{16}$ Ibid.

${ }^{17}$ Rohmalina Wahab, Psikologi Belajar (Palembang: Grafika Telindo Pres, 2014), hal.

${ }^{18}$ Observasi, op. cit.

${ }^{19}$ Ibid.
} 210. 
3. Menyenangkan.

Penataan ruangan yang rapih dan menarik, seperti yang terlihat saat observasi bahwasannya penataan ruangan kelas terlihat cukup baik, bersih, rapih, penataan kursi dan hiasan dinding yang sudah terlihat cukup rapih dan menarik. Dalam hal ini, guru melibatkan langsung siswa untuk merapihkan dan membersihkan ruangan kelas mereka dengan pembersihan dahulu setiap pagi sebelum mulai belajar dengan membuat jadwal piket setiap hari. Hal ini membuat siswa nyaman dalam kegiatan belajar mengajar yang akan berlangsung. ${ }^{20}$

Pengelolaan pembelajaran yang hidup, dari hasil wawancara dengan ibu Ely Yuslina, ia menjelaskan bahwa untuk membuat pembelajaran menjadi hidup, ia menggunakan taktik yang membuat siswa lebih berminat dan tertarik untuk belajar dengan cara menyelipkan humor pada saat menjelaskan materi pembelajaran. Dengan taktik humor siswa tidak akan bosan, selain itu dapat mencairkan suasana kelas agar tidak tegang. Ini juga sangat bisa untuk meningkatkan kecerdasan emosional siswa karena dengan humor dapat berkaitan langsung dengan mental siswa. Ia juga menjelaskan bahwa selain akademik, mental siswa sangat lah penting untuk diperhatikan, dengan humor dan pendekatan ini sangat membantu untuk perkembangan kecerdasan emosional siswa. ${ }^{21}$

Pembelajaran yang bervariasi, dari hasil observasi, saya melihat bahwa memang benar metode yang digunakan oleh guru mata pelajaran PAI bervariasi, beliau menggunakan metode (metode ceramah, tanya jawab, demontrasi, metode penugasan, metode diskusi, serta bernyanyi terkadang dilakukan, guru juga menggunakan metode cerita untuk membuat siswa tertarik kepada materi yang disampaikan, karena dengan menggunakan metode cerita siswa menjadi lebih senang dan lebih bersemangat mengikuti kegiatan belajar. ${ }^{22}$

${ }^{21}$ Wawancara dengan Ely Yuslina selaku Guru PAI SD Kelas VI SD 214 Palembang,, pada 15 Februari 2019.

${ }^{22}$ Observasi, op. cit. 
Menggunakan media dan sumber belajar yang relevan, dari hasil observasi yang dilakukan, dalam hal penggunaan media dan sumber belajar belum begitu maksimal karna guru lebih condong menggunakan hanya kepada buku pelajaran dan tidak menggunakan media lain. ${ }^{23}$

4. Menantang

Mengembangkan kemampuan berpikir, pembelajaran menantang membuat perkembangan berpikir siswa menjadi lebih optimal, ini terlihat pada saat observasi yang dilakukan dikelas, setelah guru berupaya untuk menjelaskan materi dengan baik dan dimengerti semua peserta didik kemudian setelah selesai menjelaskan materi yang sedang diberikan guru langsung menyuruh siswa untuk menjawab pertanyaan yang ia berikan, hal ini dapat merangsang kemampuan berpikir atau kerja otak siswa menjadi lebih maksimal, karena siswa berusaha untuk dapat mengerti dan menjawab pertanyaan tersebut dengan benar. ${ }^{24}$

Mengembangkan rasa ingin tahu siswa, seperti yang dijelaskan di atas, pembelajaran menantang dapat membuat siswa berusaha lebih mengoptimalkan kemampuan mereka dalam memahami pelajaran yang diberikan. Dengan ini otomatis rasa ingin tahu siswa menjadi lebih berkembang. Hal ini terlihat pada saat observasi siswa aktif untuk bertanya kepada guru. Hal ini mendorong siswa untuk lebih mengetahui hal- hal yang berhubungan dengan materi pelajaran secara lebih luas lagi. ${ }^{25}$

Melakukan eksplorasi, dari hasil observasi saya melihat bahwa dalam hal eksplorasi guru melakukan berbagai cara seperti setelah guru menjelaskan materi pelajaran sepada siswa, guru menyuruh kembali siswa untuk mengulang kembali materi pelajaran tersebut dengan cara menyuruh siswa untuk berdiskusi secara berkelompok untuk memahami dan membaca kembali materi pelajaran tersebut.

${ }^{25}$ Ibid. 
Kemudian siswa disuruh untuk menjelaskan kembali materi yang telah mereka pahami dengan cara dan pengetahuan yang telah mereka peroleh, baik dari penjelasan guru maupun dari hasil mereka berdiskusi. $^{26}$

Melaksanakan tugas belajar, dalam observasi saya melihat siswa mengerjakan tugas yang diberikan guru. Setelah guru menjelaskan materi yang sedang dipelajari guru menyuruh siswa mengerjakan latihan soal yang ada dibuku, siswapun langsung mengerjakan tugas dengan baik sampai selesai. Kemudia hasil dari tugas mereka dibahas bersama-sama dengan melibatkan siswa secara aktif. ${ }^{27}$

5. Motivasi

Menggunakan hasrat yang paling dalam untuk menggerakan dan menuntun menuju sasaran, membantu kita mengambil inisiatif dan bertindak secara efektif, serta untuk bertahan menghadapi kegagalan dan frustasi. ${ }^{28}$

Memberikan apresiasi, dalam hal ini, Ely Yuslina menyatakan bahwa biasanya saya memberikan pujian atau sanjungan kepada siswa ini berharap agar siswa dapat bersemangat dalam belajar. Pemberian pujian atau sanjungan juga salah satu cara saya untuk mengembangkan kecerdasan emosional siswa. Pujian atau sanjungan saya berikan kepada siswa yang berhasil memperoleh nilai tinggi, kepada siswa yang berhasil menyelesaikan tugas, dan kepada siswa yang berani mengajukan pertanyaan serta menjawab pertanyaan dari teman maupun guru. Hal ini perlu dilakukan agar siswa merasa senang dan termotivasi, sedangkan siswa yang lain akan berminat dan berusaha untuk melakukan hal yang sama. ${ }^{29}$

Mengarahkan perilaku siswa, dalam hal ini guru PAI yakni Ely Yuslina menyatakan dalam wawancara yakni, "saya akan memberikan hukuman bernyanyi dan membaca dengan keras di depan kelas kepada

\footnotetext{
${ }^{26}$ Ibid.

${ }^{27}$ Ibid.

${ }^{28}$ Mustaqim, Psikologi Pendidikan (Yogyakarta: Pustaka Pelajar, 2004), hal. 155.

${ }^{29}$ op. cit.
} 
siswa yang belum paham atau mengerti dengan materi yang disampaikan, atau terkadang saya juga menyuruh siswa berdiri di depan kelas biasanya siswa tersebut di dalam kelas tidak meperhatikan, mengobrol, atau sedang tidak fokus saat materi saya jelaskan. Hal ini dapat berdampak positif untuk kecerdasan emosional siswa dengan cara seperti ini terkadang membuat siswa dapat berubah menjadi lebih baik dan berusaha untuk tidak mengulangi perbuatan itu kembali." ${ }^{30}$ Dari hasil observasi yang dilakukan selain apa yang telah dijelaskan guru dalam wawancara di atas, cara guru dalam mengarahkan perilaku peserta didik yang saya lihat, guru setelah menyampaikan dan memberikan penjelasan mengenai materi pelajaran, guru memberikan tugas kepada siswa untuk mengerjakan tugas, hal ini dapat mengarahkan perilaku peserta didik. ${ }^{31}$

Mempraktekkan materi pelajaran, seperti yang dijelaskan Ibu Ely Yuslina dalam wawancara, ia mengatakan selain untuk akademik apa yang dipelajari siswa harus bisa diterapkan oleh mereka dikesehariannya. Karena menurut ia sikap dan perilaku siswa jauh lebih penting dari hanya sekedar nilai. Jika siswa sudah dapat untuk mempraktekkan materi pelajaran dikeseharian tentu akademik akan juga menjadi baik. Ia menjelaskan salah satu contoh materi pelajaran yang harus dipraktekkan seperti materi tentang sholat hal ini harus di terapkan bagi kehidupan siswa sekarang hingga nanti dan banyak lagi semua materi pelajaran harus diterapkan siswa dikeseharian mereka apalagi ini terkait dengan materi mengenai Agama Islam yang tentu memang harus dapat dipraktekkan oleh siswa. ${ }^{32}$

\section{B. Kecerdasan Emosional siswa kelas VI di SD Negeri 214 Palembang}

1. Kesadaran Diri

Mengenali emosi diri, secara garis besar emosi manusia diklasifikasi dalam dua bagian, yaitu emosi yang menyenangkan atau emosi positif, dan emosi yang tidak menyenangkan atau emosi

\footnotetext{
${ }^{30}$ Ibid.

${ }^{31}$ Observasi, op. cit.

${ }^{32}$ op. cit.
} 
negarif. ${ }^{33}$ Terlihat dalam observasi guru melakukan pendekatan dengan siswa hal ini dapat mendorong siswa untuk mengetahui emosi yang ada dalam dirinya atau emosi yang sedang mereka alami. Siswa yang telah mengenali emosi terlihat dari cara menyikapi sesuatu, ketika mereka merasa tegang atau takut mereka dapat mengatasi masalah dengan berusaha tidak bersikap berlebihan. Dan ketika mereka merasa sedih tidak begitu ditonjolkan kepada temannya yang lain dengan berusaha untuk bisa tersenyum dan melakukan kegiatan yang sama seperti temannya. ${ }^{34}$

Menunjukan keuletan, dalam observasi yang dilakukan saya melihat bahwa siswa telah menunjukan keuletan mereka, ini terlihat dari sebagian mereka yang telah mampu untuk menjalankan peraturan sekolah dengan tertib, tidak keluar masuk pada saat kegiatan pelajaran sedang berjalan serta mereka menyelesaikan tugas sekolah dengan sempurna, apa yang ditugaskan guru mereka selesaikan dengan baik dan tepat waktu dan keuletan ini juga terlihat dari siswa yang dapat mendengarkan nasihat dan mematuhi perintah yang diberkan oleh guru. ${ }^{35}$

Memahami keunggulan dan keterbatasan diri, dari observasi saya melihat bahwa, ketika guru sedang menjelaskan materi pelajaran atau menyampaikan sesuatu nasihat kepada siswa, mereka telah berusaha menerima, memahami dan mendengarkan guru dengan begitu baik dan jika belum mengerti langsung bertanya baik kepada guru maupun berdiskusi dengan temannya. Dengan ini jelas bahwa siswa telah memahami keunggulan dan keterbatasan dirinya.Guru juga telah baik menumbuhkan kesadaran siswa dengan cara menjelaskan dan menyampaikan materi dengan baik, hingga siswa dapat memahami dan berusaha untuk selalu memberikan motivasi dan nasihat-nasihat yang membangun bagi siswa. ${ }^{36}$

\footnotetext{
${ }^{33}$ Nyayu Khodijah, Psikologi Pendidikan (Depok: RajaGrafindo Persada, 2016), hal. 139.

${ }^{34}$ Observasi, op. cit.

${ }^{35}$ Ibid.

${ }^{36}$ Ibid.
} 


\section{Kontrol Diri}

Mengespresikan perasaan, dalam observasi yang dilakukan saya melihat dalam hal kontrol diri seperti yang dijelaskan di atas, bahwa siswa yang dapat mengontrol diri ialah mereka yang bisa menangani perasaan agar dapat terungkap dengan sewajarnya, dapat mengespresikannya dengan tepat. Seperti rasa senang, rasa marah, rasa sedih. Ini terlihat dari siswa yang ketika merasa senang dalam kegiatan pembelajaran mereka terlihat bersemangat dan aktif dalam proses pembelajaran serta ketika mereka dalam masalah mereka mampu mencari jalan keluar dan tidak terpuruk dalam satu situasi. Seperti contoh ketika tidak memahami pelajaran yang sedang dipelajari mereka berusaha untuk bertanya dan berusaha untuk memahaminya ini merupakan cara mereka dalam mengespresikan perasaan. ${ }^{37}$

Jujur, dalah hal kejujuran seperti yang dilihat saat observasi, sifat jujur telah terlihat dari siswa yang ketika diberikan tugas oleh guru mereka berusaha menyelesaikan sendiri atau mencari jawaban sendiri atas tugas yang diberikan tanpa mencontek atau menyalin pekerjaan temannya. Sebaliknya jika siswa tidak memiliki kontrol diri dan sifat jujur tidak tertanam dalam diri siswa, dia akan mencari jalan pintas dengan mencontek atau menyalin pekerjaan orang lain apabila ketika ada ulangan atau saat sedang mengerjakan tugas dari guru. ${ }^{38}$

Bertanggung jawab, dalam wawancara dengan guru PAI yakni Ely Yuslina menyatakan "saya akan memberikan hukuman bernyanyi dan membaca dengan keras di depan kelas kepada siswa yang belum paham atau mengerti dengan materi yang disampaikan, atau terkadang saya juga menyuruh siswa berdiri di depan kelas biasanya siswa tersebut di dalam kelas tidak meperhatikan, mengobrol, atau sedang tidak fokus saat materi saya jelaskan. Hal ini dapat berdampak positif untuk kecerdasan emosional siswa dan membuat siswa dapat menaati 
peraturan yang ada dan dapat bertanggung jawab dalam melaksanakan tugas belajar."39

3. Motivasi

Membangkitkan dorongan belajar dan memiliki hasrat mencapai tujuan, dari hasil wawancara kepada ibu Eli Yuslina, ia menjelaskan bahwa pendekatan yang biasa ia gunakan dalam proses belajar mengajar, seperti siswa yang mendapatkan nilai kecil atau sulit dalam memahami materi yang disampaikan oleh guru, berusaha untuk memotivasi siswa dengan memberikan dorongan dan semangat yang lebih kepada siswa tersebut. Siswa yang sulit untuk mengangkap penjelasan guru atau yang biasanya tidak memperhatikan itu emosionalnya belum begitu baik, dengan pendekatan bisa meningkatkan kecerdasan emosional menjadi lebih baik. ${ }^{40}$ Karena kecerdasan emosional adalah kemampuan untuk memotivasi diri sendiri dan mempertahankan diri dari keadaan frustasi, mengendalikan dorongan hati dan tidak berlebihan dalam kesenangan, mengatur suasana hati, dan menjaga agar beban stres tidak melumpuhkan kemampuan berpikir, berempati dan berdoa. ${ }^{41}$ Dari hasil observasi, saya melihat bahwa guru melakukan pendekatan dengan siswa yang kurang dalam segi nilai serta lama dapat penyerapan materi yang diajarkan, guru memberikan motivasi yang lebih kepada siswa tersebut agar mereka bersemangat dalam belajar dan mendorong siswa belajar lebih giat. $^{42}$

4. Empati

Empati merupakan kemampuan yang juga tergantu pada kesadaran diri emosional yang merupakan keterampilan bergaul dasar. Orang yang empatik lebih dapat menangkap sinyal-sinyal sosial yang tersembunyi yang mengisyaratkan apa-apa yang dibutuhkan atau

\footnotetext{
${ }^{39}$ op. cit.

${ }^{40}$ Ibid.

${ }^{41}$ Hamzah B. Uno, Orientasi Baru dalam Psikologi Pembelajaran (Jakarta: Bumi Aksara,

${ }^{42}$ Observasi, op. cit.
} 2010), hal. 68 . 
dikehendaki orang lain. ${ }^{43}$ Memahami perasaan orang lain, dari hasil wawancara dengan Ibu Ely Yuslina, ia mengatakan bahwa selain mementingkan kognitif siswa emosional siswa sangat lah penting. Karena jika emosional siswa tidak baik siswa juga tidak akan bisa menerima pelajaran yang diberikan dengan baik. Oleh karena itu kepribadian siswa harus dibimbing dan diarahkan dengan benar, apalagi saya guru Agama Islam hal ini sangat penting bagi saya. Terutama dalam pembelajaran sholat harus tertanam dengan baik di diri siswa. ${ }^{44}$

Mengembangkan kemampuan, saat observasi siswa yang mampu mengembangkan kemampuan dirinya dan temannya yang lain terlihat pada saat ia mau mengajarkan temannya yang belum mengerti terhadap apa yang telah dahulu ia ketahui seperti materi pelajaran yang sedang dipelajari atau materi pelajaran yang telah lalu begitupun sebaliknya jika mereka belum mengerti akan suatu hal sebisa mungkin mereka mencoba untuk dapat mengembangkannya. Siswa peduli dan mau untuk memberikan penjelasan atau pemahaman kepada temannya yang belum mengerti dengan senang tanpa paksaan. Jika temannya bertanya ia tidak segan untuk meberikan penjelasan atas apa yang belum dipahami dan merasa senang jika temanya yang lain dapat mengerti dan menjadi pandai. ${ }^{45}$

Memanfaatkan keberagaman, keberagaman merupakan sebuah perbedaan seperti agama, ras, suku, budaya yang harus saling menghargai. Dalam hal ini seperti yang dilihat saat observasi keberagaman tidak begitu menonjol karena pada anak kelas VI di SD Negeri 214 Palembang Agama semua Islam dan budaya suku ataupun ras juga sama karena mereka tingga dilingkungan yang sama pula. Jadi dalam hal ini tidak ada perbedaan dari siswa-siswa dalam hal keberagaman ini. Akan tetapi guru juga telah memberikan

\footnotetext{
${ }^{43}$ Darmansyah, op. cit., hal. 126.

${ }^{44}$ op. cit.

${ }^{45}$ Observasi, op. cit.
} 
pemahaman kepada siswa untuk saling menghargai perbedaan tidak mencemooh jika melihat hal yang berbeda dari orang lain. ${ }^{46}$

5. Kemampuan Sosial

Berkerjasama, dalam observasi yang dilakukan kegiatan kerjasama ini telah terlihat, seperti pada saat pembelajaran berlangsung guru sering menggunakan metode diskusi atau kerja kelompok, dengan ini siswa telah diajarkan untuk melakukan kerjasama dalam kegiatan belajar di kelas. Mereka diarahkan untuk dapat memahami materi secara bersama-sama serta mereka disuruh untuk mengerjakan tugas dengan berkerjasama dengan hal ini diharapkan siswa dapat saling berkomunikasi, saling menerima pendapat satu sama lain mendengarkan ataupun memberikan pendapatnya dan dapat bersikap saling menghargai. ${ }^{47}$

Mempengaruhi teman dengan persuasi yang baik, dalam hal ini seperti yang saya lihat dalam observasi yang dilakukan, siswa cukup bisa dalam mempengaruhi teman dengan cara yang baik dan untuk kebaikan temannya, tetapi kemampuan ini tidak begitu menonjol karena jika ada siswa yang terlihat kurang dalam penerimaan pembelajaran ataupun malas siswa lain tidak begitu mampu untuk memberikan dorongan-dorongan kepada siswa tersebut. Siswa lebih condong hanya menyerahkan hal tersebut kepada guru saja. ${ }^{48}$

Menyelesaikan masalah, dalam wawancara Ibu Ely Yuslina mengatakan bahwa, memang sering kali konflik atau permasalahan dapat terjadi di dalam suatu kelas terutama pada anak SD, dalam hal ini ia berusaha untuk menjelaskan kepada siswa bahwa ketika sedang ada suatu masalah, mereka harus mampu untuk menyelesaikan masalah dengan cara baik, Merikan pemahaman pada siswa tentang bagaimana menyelesaikan masalah yang baik. Tidak perlu ada sentuhan fisik seperti memukul, mencubit atau menggigit. Penyelesaian masalah bisa dilakukan dengan berbicara dengan cara

${ }^{47}$ Ibid.

${ }^{48}$ Ibid. 
yang baik, tentang bagaimana mengontrol sikap, juga bisa menyelesaikan masalah yang melibatkan siswa dengan mengajaknya berdiskusi, cara ini diharapkan bisa ditiru oleh siswa dan diserapnya untuk kemudian bisa diaplikasikan dalam kehidupan nyata. $^{49}$

Membangun dan menjaga hubungan, dalam observasi yang dilakukan hubungan yang terjadi ialah hubungan antara siswa dan siswa dan hubungan guru dan siswa yang terbangun dari kegiatan pembelajaran yang terjadi, dari cara guru yang harus mampu menciptakan hubungan dengan siswa dalam suatu kondisi yang memberikan pembelajaran yang aman, nyaman, menyenangkan dan kepercayaan sehingga pembelajaran tidak terkesan membosankan serta menciptakan pembelajaran yang lancar. ${ }^{50}$

\section{KESIMPULAN}

Berdasarkan penelitian yang telah peneliti lakukan, peneliti memperoleh data bahwasanya strategi guru PAI di SD Negeri 214 Palembang ini dalam mengembangkan kecerdasan emosional siswa kelas VI yaitu menggunakan interaksi belajar mengajar. Karena pada umumnya terjadinya interaksi belajar mengajar yakni, terjadinya antara tiga unsur yaitu guru, anak didik dan bahan. Bahan sebagai isi dari proses belajar mengajar yang disampaikan guru untuk diterima oleh siswa. Bahan disini sebagai perantara untuk terjadinya interaksi belajar mengajar antara guru dengan siswa dengan itu tanpa bahan tidak akan terjadi interaksi belajar mengajar. Selain itu, guru juga menggunakan kegiatan pembelajaran yang inspiratif, hal ini terlihat dari guru yang sebisa mungkin untuk menunjukan sikap dan karakter yang baik dihadapan siswa, dengan menjaga penampilan, bersemangat dalam menyampaikan materi pelajaran, bersikap murah senyum tidak selalu marah-marah kepada siswa, serta guru dapat menanamkan contoh dari sebuah kisah yang inspiratif yang dapat menjadi panutan bagi sisw. Setelah itu, penting juga melakukan penataan ruangan yang rapi dan menarik,

\footnotetext{
${ }^{49}$ op. cit.

${ }^{50}$ Observasi, op. cit.
} 
Selanjutnya, guru melakukan pengembangan rasa ingin tahu siswa, dengan cara memberikan pembelajaran yang menantang sehingga dapat membuat siswa berusaha lebih mengoptimalkan kemampuan mereka dalam memahami pelajaran yang diberikan. Dengan ini otomatis rasa ingin tahu siswa menjadi lebih berkembang. Terakhir, guru memberikan motivasi kepada siswa mengenai materi yang telah diajarkan tersebut.

Adapun kecerdasan emosional siswa kelas VI di SD Negeri 214 Palembang ini dilakukan dengan cara menumbuhkan kesadaran diri, membantu siswa dalam melakukan kontrol diri, memberikan motivasi, menanamkan sikap empati dan membentuk kemampuan sosial siswa yaitu dengan cara melakukan kerja sama sehingga hubungan antara siswa dan guru maupun siswa dengan sesama siswa dapat dibangun dan terjaga. 


\section{DAFTAR PUSTAKA}

Darmansyah. Strategi Pembelajaran Menyenangkan dengan Humor. Jakarta: Bumi Aksara, 2012.

Goleman, Daniel. Emotional Intelligence: Kecerdasan Emosional. Jakarta: Gramedia Pustaka Utama, 2015.

HM, Eli Manizar. "Mengelola Kecerdasan Emosi." Tadrib: Jurnal Pendiidkan Agama Islam 2, no. 2 (2017).

Khodijah, Nyayu. Psikologi Pendidikan. Depok: RajaGrafindo Persada, 2016.

Mahmud. Psikologi Pendidikan. Bandung: Pustaka Setia, 2012.

Mastur, A Kang. Humor Guru Sufi. Banjarmasin: Diva Pres, 2016.

Mustaqim. Psikologi Pendidikan. Yogyakarta: Pustaka Pelajar, 2004.

Nurlaila. Pengelolaan Pengajaran. Palembang: Noer Fikri, 2015.

Observasi. "di SD Negeri 218 Palembang,”.

Sugiyono. Metode Penelitian Kualitatif. Bandung: Alfabeta, 2017.

Uno, Hamzah B. Orientasi Baru dalam Psikologi Pembelajaran. Jakarta: Bumi Aksara, 2010.

Wahab, Rohmalina. Psikologi Belajar. Palembang: Grafika Telindo Pres, 2014. "Wawancara dengan Ely Yuslina selaku Guru PAI SD Kelas VI SD 214 Palembang," 2019. 